\title{
Why are people with dengue dying? A scoping review of determinants for dengue mortality
}

\author{
Mabel Carabali ${ }^{1 *}$, Libia Milena Hernandez ${ }^{2}$, Maria Jose Arauz ${ }^{3}$, Luis Angel Villar ${ }^{4}$ and Valéry Ridde ${ }^{3,5}$
}

\begin{abstract}
Background: Dengue is a viral disease whose clinical spectrum ranges from unapparent to severe forms and fatal outcomes. Although dengue death is $99 \%$ avoidable, every year around 20,000 deaths are estimated to occur in more than 100 countries. We consider that, along with biological factors, social determinants of health (SDHs) are related to dengue deaths as well.
\end{abstract}

Methods: A scoping review was conducted to explore what has been written about the role of SDHs in dengue mortality. The inclusion criteria were that documents (grey or peer-reviewed) had to include information about dengue fatal cases in humans and be published between 1997 and 2013 and written in English, Spanish, Portuguese or French. The search was conducted using a set of key words related to dengue mortality in several electronic databases: PubMed, LILACS, COCHRANE, Scielo, Science Direct, WHOLIS, OpenGrey, OpenSingle and Google Scholar. Information on SDHs was categorized under individual, social and environmental, and health systems dimensions. A summative content analysis using QDA Miner was conducted to assess the frequency of information on SDHs and its contextual meaning in the reviewed literature. The role of each SDH in dengue mortality was assessed using content analysis results.

Results: From a total of 971 documents retrieved, 78 met the criteria. Those documents were published in the Americas region (50.0 \%), Asia (38.4\%), Europe (9.0\%) and Africa (2.6\%). The described SDHs related to dengue deaths included, in the individual dimension: age, ethnicity, education, type of infection and immunological status; and in the social dimension: poverty and care-seeking behavior. The health systems dimension included access, opportunity, and quality of care, as well as health staff knowledge. Ethnicity was considered a determinant that depends on cultural and socioeconomic conditions.

Conclusions: Along with biological factors, there are several SDHs related to dengue mortality. However, only a few of these have been systematically analyzed, suggesting the need for more studies on this subject to inform the design and implementation of sustainable interventions to decrease dengue mortality. These findings nevertheless provide a better understanding of the non-biological factors involved in dengue mortality.

Keywords: Dengue, Dengue mortality, Social determinants of health, Scoping review

\section{Background}

Dengue is one of the most rapidly spread vector borne diseases and a major viral disease worldwide [1]. Dengue infection is caused by the transmission to humans of one of the four dengue virus serotypes (DENV1, DENV2, DENV3 and DENV4) through the bite of Aedes mosquitoes [2]. Over the past 50 years, dengue incidence has increased dramatically. Every year, around 100

\footnotetext{
*Correspondence: mabel.carabali@gmail.com

'International Vaccine Institute, Dengue Vaccine Initiative, SNU Research Park, San 4-8, Nakseongdae-dong, Seoul, Gwanak-gu 151-919, South Korea Full list of author information is available at the end of the article
}

million new cases are estimated to occur in 100-125 countries [1, 3]. Burdens of 96 million apparent and 293 million unapparent cases of the disease were estimated in 2010 [3, 4]. However, the real number of cases could not be identified due to the under/over-reporting or misdiagnosis of cases $[4,5]$. Therefore, in the absence of any available vaccine, treatment, or effective vector control strategies, dengue remains a challenge for public health authorities worldwide [6, 7].

The clinical spectrum of this disease ranges from unapparent or asymptomatic to severe forms and fatal

\section{() Biomed Central}

(c) 2015 Carabali et al. This is an Open Access article distributed under the terms of the Creative Commons Attribution License (http://creativecommons.org/licenses/by/4.0), which permits unrestricted use, distribution, and reproduction in any medium, provided the original work is properly credited. The Creative Commons Public Domain Dedication waiver (http:// creativecommons.org/publicdomain/zero/1.0/) applies to the data made available in this article, unless otherwise stated. 
outcomes $[8,9]$. The disease is characterized by the presence of fever, frontal headache, myalgia, arthralgia and cutaneous rash, usually self-limited to one week. Mild or asymptomatic infections are often associated with primary infections. Severe forms are characterized by the presence of hemorrhages, hypotension, thrombocytopenia and plasma leakage, also accompanied by neurological alterations [10], conditions that could eventually lead to shock and multi-systemic failure and that could worsen in presence of comorbidities $[1,8,9]$. In contexts where it is not possible to provide appropriate case management (because of limited resources, misdiagnosis or lack of knowledge), this could translate to fatal outcomes [1, 3, 8, 9]. Though dengue mortality is said to be $99 \%$ preventable, case fatality rates (CFR) far higher than $1 \%$ have been observed worldwide $[1,6,11,12]$.

Aside from intrinsic issues, foremost of which is virus infection, there are several other factors to which the increased disease incidence has been attributed. Uncontrolled urbanization, climate change and limited resources are some of the most important macro factors in this regard $[1,13-15]$. There are also other elements, referred to as social determinants of health (SDHs), which are individual, social or health systems related factors that influence the health status of individuals and society [16-18]. Determined as well by the socioeconomic or political context, SDHs play an important role in the presence and development of several diseases, as described in the 2008 final report of the World Health Organization (WHO) Commission on Social Determinants of Health (CSDH) [18]. The SDHs generally described as related to dengue are water resources, sanitation, poverty and migration [19]. Ethnicity, gender and capacity to pay for health services are also known to play a role in the presence and management of dengue disease [14, 19-21]. However, information on the role that SDHs might play in dengue mortality is very limited.

We consider that SDHs (individual, social and/or health system related), along with the virus infection and the host conditions themselves, are related to dengue mortality. We therefore conducted a scoping review of the available literature on dengue mortality and its determinants to learn what has been described about this topic.

\section{Methods}

A scoping review was conducted following the framework proposed by Arksey and O’Malley (2005) [22].

\section{Research questions}

1. What has been described about SDH and dengue mortality?

2. What SDHs have been put forward as determinants for dengue mortality?

\section{Study design and search strategy}

We conducted a scoping review of available literature using electronic databases (PubMed, LILACS, PAHO, MedCarib, COCHRANE, Scielo, Science Direct, WHOLIS, OpenGrey, OpenSingle and Google Scholar). Key words were: dengue/ dengue fever/dengue hemorrhagic/DF/DHF/DSS, mortality, fatal cases/outcome, case fatality rate, CFR, determinants, social determinants and associated factors. Both MeSH (Medical Subject Headings) terms and free-text terms were used.

\section{Inclusion criteria}

All documents in the published or grey literatures containing a report, description or analysis of fatal dengue cases in humans, and written in English, Spanish, Portuguese or French, from January 1997 to December 2013, were included. This time period was selected because the previous WHO dengue classification guidelines were published in 1997 and were valid until 2009, when the new guidelines became available [23].

\section{Screening}

After the first filter from the electronic databases, the references were saved in an EndNote library and were reviewed to identify potentially relevant papers. Those papers were assessed to determine whether they met the criteria and were then saved as potential documents. Additional sources were obtained after screening by crosschecking the references of previously identified papers.

\section{Data extraction}

The documents selected based on the inclusion criteria were then assessed independently by two reviewers; as agreement between reviewers was $>95 \%$, the team then captured the information using the data extraction form. That form was created using Epi Info $7^{\mathrm{Tn}}$ and consisted of a spreadsheet to capture general information from each document, as well as STROBE checklist items [24]. Specific information such as dengue diagnosis, classification, fatal outcomes information and SDH components was also included. Although the documents were subjected to a quality assessment, all eligible documents were included in the review, regardless of the results of that assessment (Additional file 1).

\section{Data synthesis and analysis}

General and specific information was summarized descriptively to chart the available literature (Additional file 2) . Documents were grouped according to the dengue classification used and SDHs [16] were categorized under three dimensions:

1) The individual dimension, which included characteristics such as occupation, income and education, as well as a subcategory labeled 
'biological component of the individual dimension', which comprises age, sex, comorbidities, ethnicity and host conditions such as immunological status and type of infection (primary or secondary and severe or unusual forms).

2) The social and environmental dimension, which included social subcomponent aspects such as socioeconomic and political context, war and conflict, and social behavior. In the environmental component, humidity or rain seasonality/rainfall and geographical aspects were considered. Likewise, under the environmental component, we created a subcategory labeled 'biological component of the environmental dimension' to capture information about vector presence and intrinsic virus characteristics (i.e., identification of determinate serotypes or strain virulence).

3) The health systems dimension, which included information about health care access, coverage, opportunity and quality, as well as surveillance information.

To conduct a summative content analysis [25], the gathered data was migrated to QDA Miner (Provalis Research, Montreal, Canada), where each document was considered as a case and three key word categories were created for SDHs: 'Individual,' 'Social and Environmental' and 'Health Systems'. The summative content analysis, performed first, consisted of a manifest content analysis, for which the SIMSTAT feature was used to describe frequency of SDH key words by case and in all the reviewed literature. Second, a latent content analysis was performed, in which the WORDSTAT dictionary and the documents' content were used to assess the contextual meaning of SDH key words in each case and among the reviewed documents. Using the results of the content analysis, each SDH's role in dengue mortality was then also assessed. Both the 'individual' and 'social and environmental' dimensions included a subcategory for biological determinants to avoid dissociating SDHs from biological factors that might play a role in dengue fatal outcomes.

\section{Results}

A total of 971 documents were retrieved, of which 179 were eligible and 78 were included in the review. Figure 1 describes the flow of the review.

\section{Geographical distribution, year and type of publications}

The documents reviewed had a worldwide distribution. Half were published in the Americas region $(n=39 / 78)$, with Brazil representing $46.2 \%(n=18 / 39)$ of the papers in the Americas and $23 \%(n=18 / 78)$ of the total reviewed documents. The Asia, Europe and Africa regions followed, with $38.4 \%, 9.0 \%$ and $2.6 \%$ respectively. There was an observed increasing trend in publications from 1997 to 2013 (Fig. 2).

Of the 78 documents reviewed, 60 (76.9\%) were descriptive, including single-patient or case series reports and ecological studies; 12 (15\%) were analytical studies, including cohort, case-control and cross sectional studies; and six (7.7 \%) were review articles. The main sources used to conduct studies were hospital records $(56.4 \%)$, followed by a mix of surveillance data and hospital records (33.3\%) (Table 1).

\section{Dengue and dengue mortality}

In $82 \%$ of the documents, WHO 1997 [26] guidelines were used for classifying dengue diagnosis and dengue fatal cases, while $7.7 \%$ used WHO 2009 guidelines [23]. The remaining $10.3 \%$ used other classifications, such as Ministry of Health $(\mathrm{MoH})$ adaptations of either the WHO 1997 or WHO 2009 guidelines, or the authors' own classifications constructed on the basis of clinical, laboratory or pathological findings. Cause of death was attributed exclusively to dengue in $79.5 \%(n=62)$ of the papers and to dengue and other conditions in $20.5 \%(n=16)$.

\section{SDHs described in dengue mortality literature}

Content information related to the individual dimension was found in $88.5 \%$ of the documents, health systems in $33.3 \%$ and the social and environmental dimension in $28.2 \%$. Distribution of the SDH key words by year of publication is presented in Fig. 3. Comprehensive detailed information about the manifest content analysis is provided in Table 2 .

\section{Individual dimension}

\section{Biological components of the individual dimension}

Age Individuals' chronological ages (in years or months) were described as relative or absolute frequencies of fatal dengue cases. There were more documents $(n=11)$ referring to high frequency of dengue deaths in adults [27-37] than in children $(n=5)[31,38-41]$. In two documents, age was not considered a determinant $[42,43]$.

Comorbidities These were presented either as known pre-existing conditions, such as cardiac disorders, renal transplants, diabetes, hypertension, use of anti-platelet drugs, or pregnancy and pregnancy-related conditions $[29,30,43-51]$, or as diseases confirmed during the course of dengue infection, such as concurrent bacterial infections, malaria, or other diseases [44, 52-56]. These comorbidity conditions were merely described and not explicitly reported as determinants for dengue deaths.

Type of infection and immunological status Fatal cases were reported to be more common in patients with 


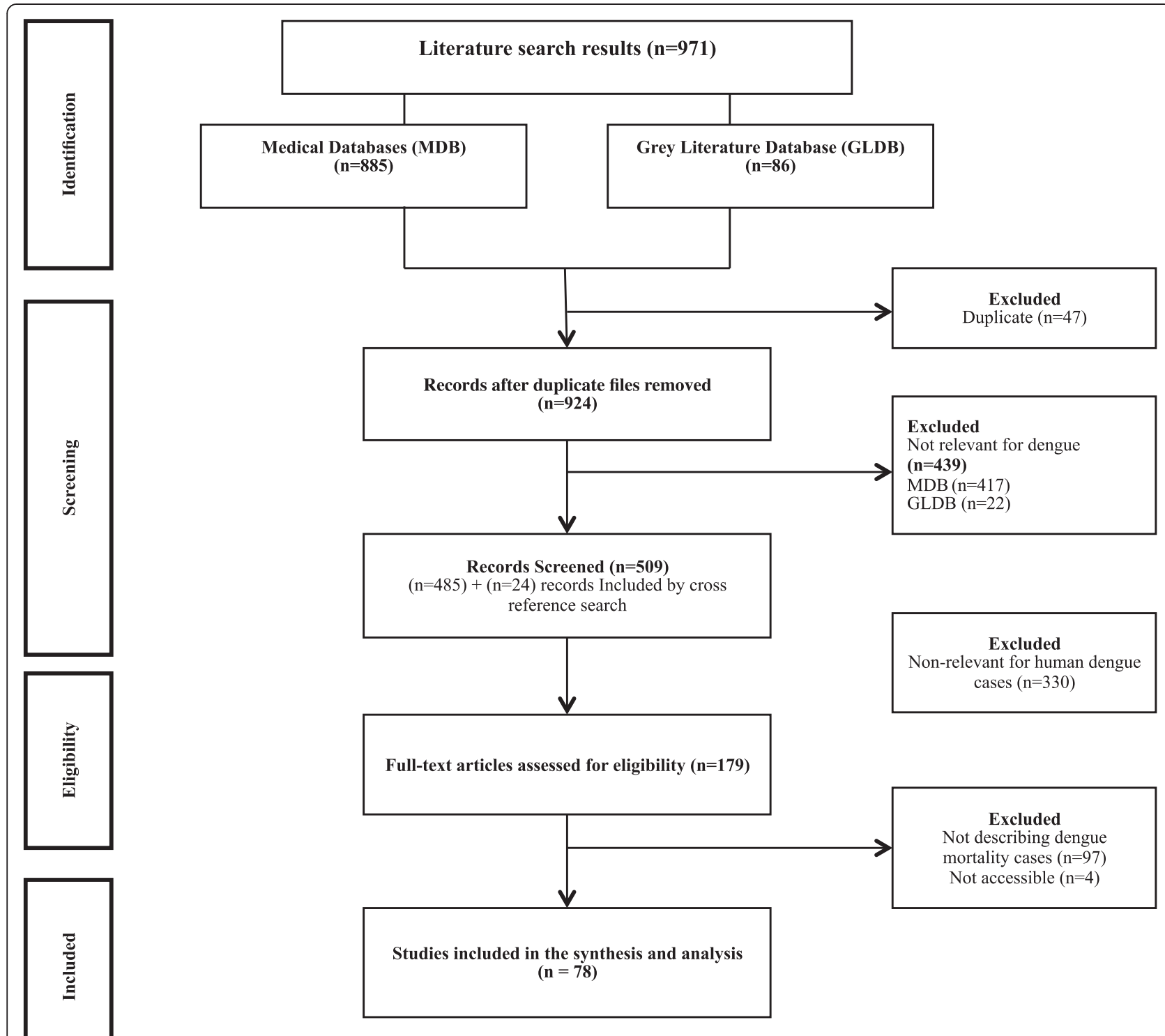

Fig. 1 Flow diagram of studies selected. Multi Database (MDB) included the following databases: PubMed $(n=144)$, ScienceDirect $(n=566)$, Scielo $(n=69)$ and VHL, covering LILACS, PAHO, MedCarib, WHOLIS, and COCHRANE-CENTRAL ( $n=10)$. Grey Literature database (GLDB) included the following databases: Social Care Online, National Institute for Health and Clinical Excellence (NICE), System for information on Grey Literature in Europe (OpenSigle), National Guideline Clearing House, Health Development Agency, National Institutes of Health, Research Service Delivery and Organization Program (SDO), Research Register for Social Care, Google Scholar and OpenGrey (the last two specifically for grey literature in Spanish or other languages)

secondary infections, dengue hemorrhagic fever (DHF), dengue shock syndrome (DSS) or severe dengue than in those with dengue fever (DF) or dengue without warning signs $[29,34,46,55,57-62]$. There was also mention that dengue mortality was greater in cases with unusual manifestations $[63,64]$. No deaths were mentioned in suspected primary infections.

Sex/Gender The terms sex and gender were used without distinction in all reviewed documents. Information ruling out the role of sex as a dengue mortality determinant was often observed [45, 47, 52, 59, 63, 65-72]. Greater frequency of mortality in men was reported in 18 papers $[35,37,39,41-43,55,64,73-81]$, whereas seven reported higher frequencies in women [27, 29, 30, 32, 58, 82, 83]. There was no description of significant differences between sexes in the presentation of fatal cases.

Ethnicity This was reported either as the ethnic group to which individuals belonged or by mentioning their country 


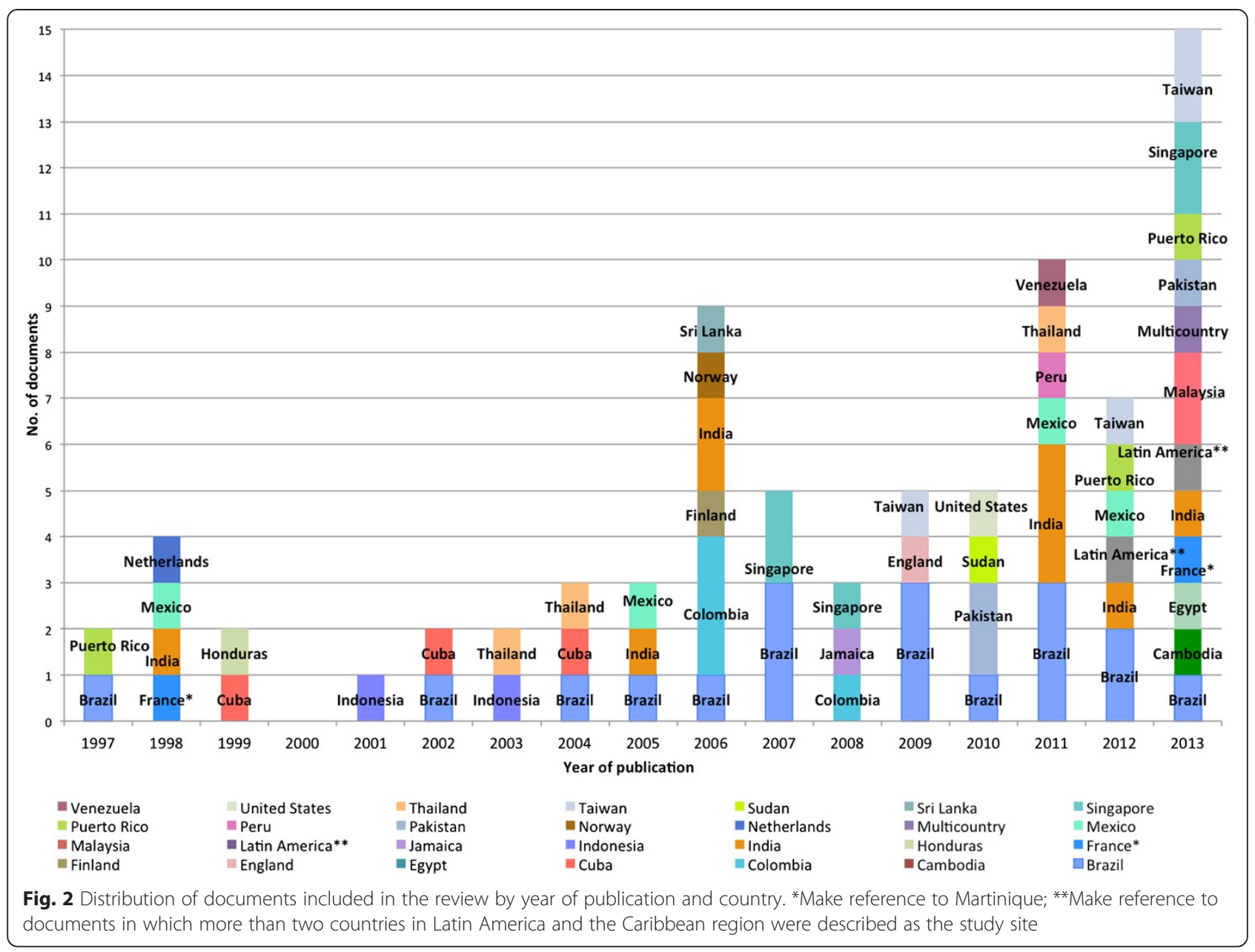

of origin or self-assessment of their ethnicity. Descriptions included: Indians [30, 80, 84], Chinese [30, 54, 80, 85, 86], Malay [30, 80], Bangladeshi [30], African ancestry/'Blacks' or brown [27, 29, 35, 37, 87, 88], 'Whites' [27, 29, 35, 37, 82, 89, 90], and 'Mixed' [29, 37, 39]. Some papers described equivalent risk among all ethnic groups [52, 54, 60, 91], whereas others noted a protective role among Africans or persons of African ancestry [87], higher risk for severe forms among Whites [37], or that being Black or of African ancestry was determinant for dengue mortality [88].

\section{Non-biological components of the individual dimension}

Occupation Described as either work status or activities performed, occupation was most often presented in the single or series case reports. Those whose occupation was defined by activities included students, housewives, army members, and non-qualified workers, among others [32, 42, 58].

Income This component was not mentioned at the individual level, but was presented only as a variable of the
Human Development Index (HDI) at the country or regional level [92].

Education Only a few documents described education, usually by reporting the educational profile of the cases $[32,35]$. One document showed an association between low education and dengue mortality [88].

\section{Social and environmental dimension}

Socioeconomic and political context Two papers discussed the socioeconomic and political context by describing dengue as a political issue [93] and the development of the disease in a city considered to be an economic hub [27].

Poverty This was either described directly as the society's economic situation or expressed as the HDI. Poverty was reported as a partial explanation for dengue deaths [87], and high CFRs were reported in low HDI countries [92]. 
Table 1 Characteristics of studies reviewed

\begin{tabular}{|c|c|}
\hline Characteristics & n (\%) \\
\hline Number of reviewed studies & 78 \\
\hline \multicolumn{2}{|c|}{ Total no. of individuals included in the studies } \\
\hline Described number of dengue cases & $1,900,499$ \\
\hline Described number of fatal cases & 8,650 \\
\hline \multicolumn{2}{|l|}{ Region of publication } \\
\hline Americas & $39(50)$ \\
\hline Asia & $30(38.4)$ \\
\hline Europe & $7(9.0)$ \\
\hline Africa & $2(2.6)$ \\
\hline \multicolumn{2}{|l|}{ Dengue case classification used } \\
\hline WHO 1997 & $64(82)$ \\
\hline WHO 2009 & $6(7.7)$ \\
\hline Other $^{\mathrm{a}}$ & $8(10.3)$ \\
\hline \multicolumn{2}{|l|}{ Type of study } \\
\hline Descriptive & $60(76.9)$ \\
\hline Analytical & $12(15.4)$ \\
\hline Review & $6(7.7)$ \\
\hline \multicolumn{2}{|l|}{ Source of information } \\
\hline Surveillance data & $3(3.8)$ \\
\hline Articles (for review documents) & $5(6.5)$ \\
\hline Hospital chart and surveillance & $26(33.3)$ \\
\hline Hospital charts & $44(56.4)$ \\
\hline \multicolumn{2}{|l|}{ Study setting } \\
\hline Hospital based & $43(55.1)$ \\
\hline Population based & $27(34.6)$ \\
\hline Other & $8(10.3)$ \\
\hline \multicolumn{2}{|l|}{ Primary outcome } \\
\hline General description of dengue cases & $55(70.5)$ \\
\hline Specific description of dengue fatal cases & $23(29.5)$ \\
\hline \multicolumn{2}{|l|}{ Described cause of death } \\
\hline Only dengue & $62(79.5)$ \\
\hline Dengue and other conditions & $16(20.5)$ \\
\hline \multicolumn{2}{|l|}{ Overall study quality ${ }^{\mathrm{b}}$} \\
\hline Well conducted & $40(51.3)$ \\
\hline Could be improved & $38(48.7)$ \\
\hline
\end{tabular}

${ }^{a}$ Dengue cases classification defined by the document's authors and does not correspond to official WHO guidelines

${ }^{b}$ Quality assessment performed according to STROBE checklist (http://www.strobe-statement.org)

Social behavior The absence or delay of care-seeking was presented as an explanation for severe/fatal outcomes [77]. Dengue death was described as occurring more often in patients who sought care after the fourth or fifth day of fever, whereas those who recovered had generally sought care during the first three days [29-31, 76, 80, 93]. CFR decrease was attributed to increased awareness of dengue disease [91].

Environmental Conditions such as humidity or rain seasonality/rainfall were related with the occurrence of outbreaks [27, 92, 94, 95]. Geographical barriers (e.g. distance or transportation constraints on access to health services) were not considered determinants of dengue mortality [93]. In one paper, rural residence was associated with higher probability of death by severe dengue [88].

\section{Biological components of the environmental dimension}

Vector presence Increased dispersion of the vector, vector control difficulties, urban growth and increasing population mobility were important conditions determining vector and disease presence $[87,94,96,97]$.

Virus characteristics Described either by the specific causal serotype, the serotype virulence or the effect of serotype combination, virus characteristics were present in 25 reviewed documents describing fatal cases [11, 29, 32, 33, $37-41,52,55,60,62,66,70,73,76,79,80,83,88,98-101]$.

\section{Health systems dimension}

Access Papers described facilities where patients were managed (primary, secondary or tertiary level of care) or type of service accessed (private or public) [39, 69, 77]. Also described were barriers to health care access, including cases where patients died during the referral process, upon arrival at the facility, or after visiting a health facility outside of office hours [30-32, 40, 61, 65, 77].

Health coverage An increase in population health coverage due to increased government health expenditure (GHE) was described as playing a determinant role in reducing dengue mortality. In some cases, overrepresentation of the private sector was related to limitations in disease management and consequent worse outcomes $[92,94]$.

Opportunity Opportunity is defined as the condition in which health care is provided to the patient at the appropriate time. In nine articles, difficulties of opportunity were noted in diagnosis, case management and the referral process [30-32, 40, 65, 69, 88, 93, 102].

Quality of care Qualitative descriptions of health care were presented in six documents. Descriptions covered good praxis, misdiagnosis, mismanagement (by early discharge, non-correction of shock, non-use of lab tests), or 'wrong praxis' related to both scientific and technical qualities [32, 40, 65, 69, 77, 93, 102]. 


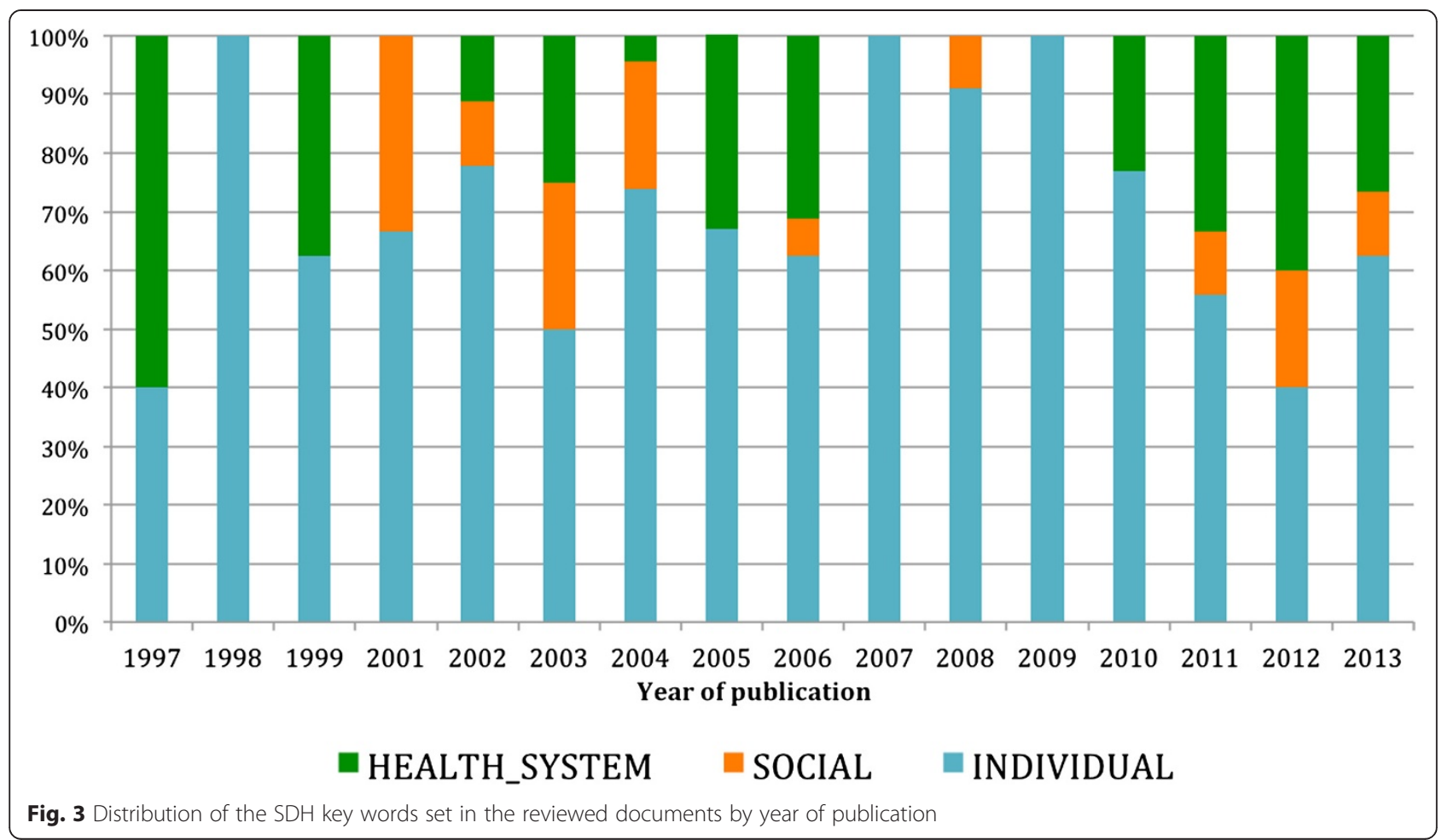

Duration of hospitalization This was reported as total number of days and/or average length of hospital stay in days, rather than as an association between length of stay and health outcomes [11, 69, 103]. Some documents described a rapid occurrence of death (at arrival or within the first $24 \mathrm{~h}$ ) $[30,32,40,65,80]$. Others showed that death often occurred only after the third day, with hospitalizations sometimes extending more than 20 days $[29,39,80]$.

Health staff knowledge This was described as the presence of any knowledge about diagnosis or cases management and the quality of that knowledge (i.e., adequate or inadequate). Some papers noted that adequate or improved patient management by health staff had a positive effect in terms of declining dengue mortality $[32,51,65,91,93,102]$.

Surveillance This was reported as the presence or absence of a surveillance system in the study settings. The need for systematic and integrated surveillance to improve health care services was often noted [32, 51, 69, 91, 92, 94].

In summary, according to the reviewed literature, the SDHs considered to be determinants for dengue mortality were: age, type of infection, ethnicity, education, poverty, care-seeking behavior, access, opportunity and quality of care, and health staff knowledge. The latent content analysis is described in Tables 3, 4 and 5.

\section{Discussion}

This scoping review provides detailed information on the social determinants of health in dengue fatal outcomes. From an extensive exploration of the literature, this review compiled 16 years of worldwide data providing valuable information to analyze the role of SDHs in dengue mortality in endemic countries. While there are reviews exploring determinants of mortality, these have been mainly regionally and biomedically oriented [11, $29,55,80,88,92]$. This is the first review, to our knowledge, to explore the role of SHDs as determinants for dengue mortality with a global scope.

Different types of documents were reviewed, with different study designs, outcomes and sources. However, there was a notable lack of qualitative or social sciences oriented studies. This might be due to the fact that available information about dengue cases is usually focused on biological factors and the available evidence is published in biomedical databases [88, 93]. Nonetheless, even if SDHs are known to play an important role in people's health $[19,104,105]$, the lack of literature on the links between SDHs and specific health outcomes is understandable. It may be more feasible and suitable to find associations between biological variables and biological outcomes, which are both easier to understand and to prove, and which is not the case for nonbiological factors $[18,19,106]$. Analyzing SDHs is a very complex undertaking, and in the case of multifactorial 
Table 2 Frequency of information about individual, social and health systems dimension of SDHs

\begin{tabular}{lll}
\hline Characteristics & \multicolumn{2}{l}{ Presence of information } \\
\cline { 2 - 3 } & Yes (\%) & No (\%) \\
\hline Individual dimension & $75(96.2)$ & $3(3.8)$ \\
Age & $30(38.5)$ & $48(61.5)$ \\
Comorbidities & $40(51.3)$ & $38(48.7)$ \\
Type of infection & $14(17.9)$ & $64(82.1)$ \\
Immunological status & $67(85.9)$ & $11(14.1)$ \\
Sex/Gender & $17(21.8)$ & $61(78.2)$ \\
Ethnicity & $3(3.8)$ & $75(96.2)$ \\
Occupation & $1(1.3)$ & $77(98.7)$ \\
Income & $3(3.8)$ & $75(96.2)$ \\
Education & & \\
Social and environmental dimension & $3(3.8)$ & $75(96.2)$ \\
Political context & & $78(100)$ \\
War or Conflict & $2(2.6)$ & $76(97.4)$ \\
Poverty & $4(5.1)$ & $74(94.9)$ \\
Social Behavior & $4(5.1)$ & $74(94.9)$ \\
Environmental - Vector Presence & $25(32.1)$ & $53(67.9)$ \\
Virus characteristics & & $67(89)$ \\
Health system related & $13(16.7)$ & $65(83.3)$ \\
Specifications about health System & $6(7.7)$ & $72(92.3)$ \\
Access to health care & $2(2.6)$ & $76(97.4)$ \\
Health coverage & $9(11.5)$ & $69(88.5)$ \\
Opportunity for receiving attention & $4(5.1)$ & $74(94.9)$ \\
Quality of attention received & $10(12.8)$ & $68(87.2)$ \\
Length of hospital stay & $11(14.1)$ & $67(85.9)$ \\
Health staff knowledge & $98.5)$ \\
\hline & & \\
\hline
\end{tabular}

neglected tropical diseases (NTDs) like dengue, exploring interactions among results is far more complicated [19]. There were only two articles specifically addressing the topic in this review, one discussing the role of the health system using a qualitative approach [93] and the other, with a quantitative approach, exploring the role of social determinants in dengue mortality using a national surveillance dataset [88]. Still, there is currently an interest in exploring the relationship between $\mathrm{SDHs}$ and health $[19,104-106]$, and this type of review has much to contribute in this area.

We expected to find more documents from the Asia region due to its large dengue presence. These sparse results may be due to the fact that CFRs there decreased after the 1980s $[1,10,107]$, such that there was less reported dengue mortality during the time covered by the review. In contrast, CFRs in the Americas region have increased significantly over recent years [5, 11, 15, 107]. The African region, on the other hand, was a special case. Obtaining information about dengue in African countries remains a challenge, and very little is known about severe cases and mortality [5, 108]. In this review, while there were few articles on Africa, those were very valuable, showing an emergent interest in dengue research in Africa. Nonetheless, under-reporting and difficulties associated with attributing dengue as the cause of death are reflected in the limited available information overall [3-5]. Therefore, given the nature of the topic and the heterogeneity of the documents found, we felt that a scoping review including content analysis was a suitable methodology that would allow us to better analyze and understand the findings.

Social determinants of health related to dengue mortality Age was described as a determinant related to immunological status and type of infection [1, 8, 9, 107]. Interestingly, despite the fact that reported mortality rates were higher in adults, children's cases seemed to be more sensitive from a sociocultural perspective and generated greater concern. Moreover, fatal outcomes in children were described as also being dependent on health staff and parents' awareness of the disease, implying that children's outcomes depend not only on age, but also on adequate management by health staff and opportune care-seeking behavior by parents $[29,37,38,93,107]$. Likewise, ethnicity was considered to be a determinant for dengue mortality despite the known biological implications. For instance, while some papers have posited African ancestry or being 'Black' as a protective factor for severe forms and dengue mortality [107, 109-112], this review found a paper from Brazil contradicting that position [88]. We observed that when the protective role of African ancestry was demonstrated in other studies, socioeconomic information was not taken into account, and that when this information was considered as a possible risk factor, the social aspect appeared as a co-determinant. This could be related to the fact that people of African ancestry in the Americas tend to live in unfavorable socioeconomic conditions [88]. Hence, it is not the fact of being 'Black' in Brazil that increases the chances of dying from dengue, but rather living in unfavorable socioeconomic conditions, as presented by Blanton et al. in 2008 [109]. When both ethnicity and income were addressed, and even after controlling for income, African ancestry (both self-reported and genotyped) was a protective factor for severe forms of dengue. As such, ethnicity would not be a determinant on its own but is linked with socioeconomic position and opportunity for access to qualified services $[18,19,88]$.

Education is a determinant with a twofold effect on dengue mortality. First, educated people will understand the importance of the disease and its risks, seek care 
Table 3 Individual dimension aspects related to dengue mortality according to content analysis

\begin{tabular}{|c|c|c|c|}
\hline \multirow{2}{*}{$\begin{array}{l}\text { Individual dimension } \\
\text { SDH }\end{array}$} & \multicolumn{2}{|c|}{ Consideration as determinant for dengue mortality } & \multirow[t]{2}{*}{ References } \\
\hline & Concept $^{a}$ & Observations & \\
\hline \multirow[t]{4}{*}{ Age } & \multirow[t]{4}{*}{ Yes } & - Age was more often described as a determinant than not. & \multirow[t]{4}{*}[27-43]{} \\
\hline & & $\begin{array}{l}\text { - In children the most affected group were those }<15 \text { years } \\
\text { old with an emphasis on the group of }<5 \text { years old. }\end{array}$ & \\
\hline & & $\begin{array}{l}\text { - A higher frequency of dengue mortality was reported in adults } \\
\text { (mostly in the Americas region) }\end{array}$ & \\
\hline & & $\begin{array}{l}\text { - Determinant related with immunological status, type of infection } \\
\text { and comorbidities. }\end{array}$ & \\
\hline \multirow[t]{3}{*}{$\begin{array}{l}\text { Comorbidities/ } \\
\text { Pre-existing conditions }\end{array}$} & \multirow[t]{3}{*}{ NC } & $\begin{array}{l}\text { - Although these conditions might worsen the dengue status, there } \\
\text { were not described as directly related to fatal outcomes. }\end{array}$ & \multirow[t]{3}{*}[29,30,43-56]{} \\
\hline & & $\begin{array}{l}\text { - Overlaps of diseases make differential diagnosis difficult and could be } \\
\text { considered as independent causes of death. }\end{array}$ & \\
\hline & & - The most cited were diabetes, bacterial infections and pregnancy. & \\
\hline $\begin{array}{l}\text { Infection type/ } \\
\text { Immunological status }\end{array}$ & Yes & $\begin{array}{l}\text { - Secondary infections, severe forms and unusual presentations were } \\
\text { described as determinants. }\end{array}$ & {$[29,34,46,55,57-64]$} \\
\hline \multirow[t]{3}{*}{ Sex/Gender } & \multirow[t]{3}{*}{ NC } & $\begin{array}{l}\text { - More dengue cases were described in women, even though the } \\
\text { majority of dengue deaths were reported in men. }\end{array}$ & \multirow[t]{3}{*}{$\begin{array}{l}{[27,29,30,35,37,39,41-43,45,47,} \\
52,55,58,59,63-83]\end{array}$} \\
\hline & & $\begin{array}{l}\text { - Statistically significant differences were described between sexes in } \\
\text { dengue in severity but not in mortality. }\end{array}$ & \\
\hline & & $\begin{array}{l}\text { - Gender differences in frequency were related to care-seeking } \\
\text { behavior patterns. }\end{array}$ & \\
\hline \multirow[t]{2}{*}{ Ethnicity } & \multirow[t]{2}{*}{ Yes } & $\begin{array}{l}\text { - A protective role was described for African ancestry/'Blacks' and a } \\
\text { risk factor for Caucasian/ 'Whites'. }\end{array}$ & \multirow[t]{2}{*}{$\begin{array}{l}{[27,29,30,35,37,39,52,54,60,80,} \\
84-91]\end{array}$} \\
\hline & & $\begin{array}{l}\text { - Described also as determinant related to socioeconomic status } \\
\text { and cultural behaviors. }\end{array}$ & \\
\hline Occupation & No & $\begin{array}{l}\text { - Some occupations were listed (mostly in the single case reports) } \\
\text { but none was directly linked to fatal outcome. }\end{array}$ & {$[32,42,58]$} \\
\hline \multirow[t]{2}{*}{ Income } & \multirow[t]{2}{*}{ No } & - There were no individual reports on the fatal cases' income. & \multirow[t]{2}{*}[92]{} \\
\hline & & $\begin{array}{l}\text { - Although it is related to socioeconomic status, income was not } \\
\text { reported as a determinant for dengue mortality. }\end{array}$ & \\
\hline \multirow[t]{2}{*}{ Education } & \multirow[t]{2}{*}{ Yes } & - Level of education was described in some cases. & \multirow[t]{2}{*}[32,35,88]{} \\
\hline & & $\begin{array}{l}\text { - In the content analysis, it was observed that education was } \\
\text { described as a determinant for dengue mortality related to } \\
\text { knowledge of patients and health staff. }\end{array}$ & \\
\hline
\end{tabular}

${ }^{a}$ Concept according to what was described in the literature. YES Considered to be a determinant, NO Not considered to be a determinant, NC Non-conclusive information

opportunely and adhere to treatment $[1,17,88]$. Second, educated health staff will manage patients accurately, thereby decreasing their chances of developing severe forms, which in turn reduces dengue mortality [32, 91, 93, 107]. Furthermore, the level of education (and awareness) of individuals could be a proxy for poverty (and poor quality of facilities), since it is related to the quality of life of individuals and societies and to the quality of the health system [16-19].

Type of dengue infection, virus characteristics and immunological status of the individual are known biological determinants of severe forms and fatal outcomes of dengue [3, 6, 8, 9, 13, 33, 37, 67, 107, 110, 113]. However, it is known that individuals' immunological status is also related to socioeconomic status (SES) [19, 104, 105]. Moreover, in the case of dengue, type of infection and immunological status will depend on previous exposure to the virus. Acting as a selective pressure, previous exposure induces changes in the virus and allows it to remain in a determinate region, leading to endemicity $[1,6,7,9,19,23]$. As such, those determinants, along with their biological implications, could also be considered an outcome of the socioeconomic and environmental conditions in which people are living.

Poverty and social behavior were considered to be general (wide-ranging) social dimension determinants for dengue mortality, related to income, education and health systems. Lack of economic resources is often associated with the presence of dengue $[1,6,7,19,109]$. Poverty will also have an impact on access to health care, since in many developing countries access is determined by capacity to pay $[16,18]$. Likewise, poverty could limit access 
Table 4 Social and environmental dimension aspects related to dengue mortality according to content analysis

\begin{tabular}{|c|c|c|c|}
\hline \multirow{2}{*}{$\begin{array}{l}\text { Social and environmental dimension } \\
\text { SDH }\end{array}$} & \multicolumn{2}{|c|}{ Consideration as determinant for dengue mortality } & \multirow[t]{2}{*}{ References } \\
\hline & Concept $^{a}$ & Observations & \\
\hline \multirow[t]{2}{*}{ Poverty } & \multirow[t]{2}{*}{ Yes } & $\begin{array}{l}\text { - Contributes directly to income, education and living } \\
\text { conditions. }\end{array}$ & \multirow[t]{2}{*}[87,92]{} \\
\hline & & $\begin{array}{l}\text { - Represents a barrier for access to health care and thereby } \\
\text { contributes to rise in dengue mortality. }\end{array}$ & \\
\hline \multirow[t]{2}{*}{ Social behavior } & \multirow[t]{2}{*}{ Yes } & $\begin{array}{l}\text { - Absence or delays in care-seeking were described as } \\
\text { explaining dengue mortality. }\end{array}$ & \multirow[t]{2}{*}[29-31,76,77,80,91,93]{} \\
\hline & & $\begin{array}{l}\text { - Reflects social and cultural aspects and is related to } \\
\text { risk perception and awareness of disease by patients } \\
\text { and health staff. }\end{array}$ & \\
\hline \multirow[t]{2}{*}{ Environmental/vector presence } & \multirow[t]{2}{*}{ NC } & $\begin{array}{l}\text { - Rural residence and geographical barriers were more related } \\
\text { to access to health care than to dengue mortality itself. }\end{array}$ & \multirow[t]{2}{*}[27,87,88,92-97]{} \\
\hline & & $\begin{array}{l}\text { - Vector presence and occurrence of dengue outbreaks were } \\
\text { described as a condition that increased the risk of severe } \\
\text { forms of dengue. }\end{array}$ & \\
\hline \multirow[t]{2}{*}{ Virus characteristics } & \multirow[t]{2}{*}{ Yes } & $\begin{array}{l}\text { - Heterogeneous infections and virulence of strains might } \\
\text { increase disease severity }\end{array}$ & \multirow{2}{*}{$\begin{array}{l}{[11,29,32,33,37-41,52,55,60} \\
62,66,70,73,76,79,80,83,88 \\
98-101]\end{array}$} \\
\hline & & $\begin{array}{l}\text { - Together with type of infection/immunological status, was } \\
\text { described as an important determinant. }\end{array}$ & \\
\hline
\end{tabular}

${ }^{a}$ Concept according to what has been described in the literature. YES Considered to be a determinant, NO Not considered to be a determinant, NC Non-conclusive information

to care in remote areas [17-19]. It is also known that lack of economic resources may lead to fatal outcomes and have devastating economic implications $[11,21,87,92$, 94]. Furthermore, society is moved by cultural or idiosyncratic patterns, whether hierarchical, economic, power or gender-oriented, that affect people's health status $[16-19,104]$. Some documents in this review observed that care-seeking behavior may determine the possibility of receiving opportune treatment and thereby avoiding fatal outcomes [29, 30, 76, 77, 80, 93]. A relationship was also observed between care-seeking behavior patterns and gender, in accordance with societal cultural behaviors [18, 19, 35, 93, 94].

The health systems determinants related to dengue mortality were access to health care, opportunity and quality of care, and health staff knowledge. Indeed, health systems play a determinant role in the health outcomes of people, as mentioned by the CSDH [16-18].

Table 5 Health systems dimension aspects related to dengue mortality according to content analysis

\begin{tabular}{|c|c|c|c|}
\hline \multirow{2}{*}{$\begin{array}{l}\text { Health systems dimension } \\
\text { SDH }\end{array}$} & \multicolumn{2}{|c|}{ Consideration as determinant for dengue mortality } & \multirow[t]{2}{*}{ References } \\
\hline & Concept $^{a}$ & Observations & \\
\hline \multirow[t]{2}{*}{ Access to health care } & Yes & $\begin{array}{l}\text { - Lack of access or presence of barriers to health care and/or } \\
\text { supplementary services were often }\end{array}$ & {$[30-32,39,40,61,65,69,77]$} \\
\hline & & - described in dengue mortality. & \\
\hline Health coverage & NC & $\begin{array}{l}\text { - Although health coverage might facilitate the access and health care } \\
\text { attention received, it was not specifically described as determinant. }\end{array}$ & {$[92,94]$} \\
\hline $\begin{array}{l}\text { Opportunity for receiving } \\
\text { attention }\end{array}$ & Yes & $\begin{array}{l}\text { - Limitation in referrals, shock corrections, delayed attention, or } \\
\text { early hospital discharge were the most described aspects related } \\
\text { to opportunity for attention. }\end{array}$ & $\begin{array}{l}{[30-32,40,65,69,88,93,} \\
102]\end{array}$ \\
\hline $\begin{array}{l}\text { Quality of attention } \\
\text { received }\end{array}$ & Yes & $\begin{array}{l}\text { - Related as well to health staff knowledge, both technical and scientific } \\
\text { quality of attention were described as direct determinants in the cases } \\
\text { with wrong praxis. }\end{array}$ & {$[32,40,65,69,77,93,102]$} \\
\hline Length of hospital stay & NC & $\begin{array}{l}\text { - This item was reported by describing the duration of a hospital stay, } \\
\text { but without reporting any association with fatal outcomes. }\end{array}$ & $\begin{array}{l}{[11,29,30,32,39,40,65,69,} \\
80,103]\end{array}$ \\
\hline Health staff knowledge & Yes & $\begin{array}{l}\text { - Expressed as appropriate management of the disease, thereby decreasing } \\
\text { the chance of developing severe forms and dengue mortality. }\end{array}$ & {$[32,51,65,91,93,102]$} \\
\hline Surveillance & No & $\begin{array}{l}\text { - Described as a tool for cases analysis and documentation of outbreaks but } \\
\text { not as a determinant. }\end{array}$ & {$[32,51,69,91,92,94]$} \\
\hline
\end{tabular}

${ }^{a}$ Concept according to what has been described in the literature. YES Considered to be a determinant NO Not considered to be a determinant, NC Non conclusive information 
Access to health care is nevertheless mediated by other SDHs, such as income and poverty [16, 18-20, 104, 114], and it is therefore essential to recognize that limited access to health care may contribute to the development of dengue fatal outcomes [3, 19, 21, 30-32, 40, 92]. In addition, opportunity and quality of care and health staff knowledge are determinants related to education in several ways. In the case of opportunity for care, empowered and diseaseaware individuals tend to seek care opportunely [19] and knowledgeable staff tend to offer opportune management to dengue patients $[18,19]$. When care is not offered opportunely, the risk of dengue fatal outcomes is theoretically doubled [27, 31, 55, 61, 80, 88, 93, 102]. As for quality of care and health staff knowledge, trained personnel translate into better case diagnosis and management, and consequently low mortality rates $[32,91,93,107,114]$. Therefore, the above-mentioned health systems related determinants must figure prominently in any strategy targeting a decrease in dengue mortality.

\section{Described SDHs non-related to dengue mortality}

Although sex/gender was not considered a determinant for dengue mortality in this review, some authors observed that its role in fatal outcomes depended on care-seeking behavior, which in turn depended on sociocultural aspects $[27,88,94]$. As gender, being socially constructed, is differentiated from sex, and since gender roles interact in different forms with NTDs [18, 19], further research on this topic would be interesting. In the case of dengue, it might not be sex, but rather careseeking behavior driven by gender, that determines the outcome $[4,88]$. With regard to the presence of comorbidities or pre-existing conditions, the information provided in the reviewed documents was not specific and therefore not conclusive enough to consider it a determinant for dengue mortality. Nonetheless, it is important to acknowledge that comorbidities might aggravate the disease, as has already been stated $[8,12,110]$. Likewise, although income and occupation were not described as determinants, these two variables are related with socioeconomic status and will depend on education as well. Hence they are considered social determinants in relation to many infectious diseases, including dengue $[18,19,109]$.

Very few documents provided information on environmental factors, and neither the few environmental factors described nor vector presence, were considered direct determinants for dengue mortality. Aspects such as urban residence or level of urbanization were reported only when describing dengue cases but not when informing about fatal cases. Nonetheless, vector presence could depend on virus presence and social behaviors (community or government actions). Moreover, vector control is the current feasible strategy for dengue control while waiting for vaccine development $[1,3,6,9,13,14]$. Neither health care coverage nor hospital length of stay was conclusive as a determinant for dengue mortality. Opportunity for care by health staff might be related to coverage and access to health care, and hospital length of stay might be related to quality of care and health staff knowledge. These conditions, along with the presence of a surveillance system, are useful aspects to consider when analyzing the presence of dengue and its outcomes.

\section{Strengths and limitations}

This review's inclusiveness and the comprehensiveness of the analysis are major strengths. Including a great variety of documents and conducting a review in four languages helped reduce selection bias and increased the scope of the information in this type of review [22]. However, the fact that we did not include documents written in native languages from the Asia region (Thai, Vietnamese, Indonesian, etc.) could have limited the number of documents reviewed from that region. Likewise, it is possible that the Americas region was over-represented by the fact that the review included documents written in Spanish and Portuguese. A summative content analysis [25] of dengue mortality documents provided comprehensive and detailed information on the topic over the past 16 years. It is important to acknowledge that, despite the substantial dengue literature, information on fatal cases is still limited and is mostly of a biomedical nature. Moreover, access to some documents was not possible. An added challenge is the fact that it is not always possible to distinguish between SDHs and biological factors, nor to identify their determinant roles separately $[18,19,104]$. Notwithstanding the above-mentioned limitations, this scoping review offers valuable information on the role of SDHs in dengue mortality.

\section{Conclusions}

Dengue is a multifactorial disease, and although there is much information on the presence of the disease, there is limited information on the causes of dengue mortality. These findings reveal that, along with biological factors, SDHs play an important role in dengue fatal outcomes. However, only a few of these determinants have been systematically analyzed. Moreover, findings show that even in the presence of available guidelines for disease management and strong commitment to dengue control, there are still many people dying from a $99 \%$ avoidable cause of death, attesting to the need for more studies on the role of SDHs in dengue mortality. Studies that reveal the important SDHs involved in dengue mortality will help policymakers and health practitioners build better and more sustainable interventions to reduce dengue mortality rates worldwide. 


\section{Additional files}

Additional file 1: Table S1. Scoping Review dengue mortality and SDH database: Spreadsheet with the information from the reviewed

documents. (XLSX $84 \mathrm{~kb}$ )

Additional file 2: Table S2. PRISMA checklist. Format. (DOC 62 kb)

\section{Abbreviations}

CFR: Case fatality rates; CSDH: Commission of social determinants of health; DENV: Dengue virus; DF: Dengue Fever; DHF: Dengue Hemorrhagic Fever; DSS: Dengue Shock Syndrome; HDI: Human Development Index; GHE: Government Health Expenditure; MeSH: Medical Subject Headings; $\mathrm{MoH}$ : Ministry of Health; NTD: Neglected tropical diseases; SDH: Social determinants of Health; SES: Socioeconomic status; WHO: World Health Organization.

\section{Competing interests}

The authors declared that they have no competing interests.

\section{Authors' contributions}

MC, LAV and VR conceived and designed the study. MC and LMH performed the search and data extraction. MC and VR analyzed the data. MC wrote manuscript. MC, MJA, LMH, LAV and VR reviewed and edited the manuscript. All authors read and approved the final manuscript.

\section{Acknowledgements}

We would like to acknowledge Daniela Ziegler, Librarian at the University of Montreal Hospital (CHUM) for her help with the search methodology. Thanks also to Lyda Osorio and Jay Kaufman for comments and revision of the manuscript and to Donna Riley for English editing.

\section{Funding}

This work did not receive any supporting grants. VR holds a CIHR-funded Research Chair in Applied Public Health (CPP 137901).

\section{Author details}

${ }^{1}$ International Vaccine Institute, Dengue Vaccine Initiative, SNU Research Park, San 4-8, Nakseongdae-dong, Seoul, Gwanak-gu 151-919, South Korea. ${ }^{2}$ Centro de Atencion y Diagnostico de Enfermedades Infecciosas (CDI), Bucaramanga, Santander, Colombia. ${ }^{3}$ School of Public Health (ESPUM), University of Montreal, Montreal, Quebec, Canada. ${ }^{4}$ Universidad Industrial de Santander, Bucaramanga, Santander, Colombia. ${ }^{5}$ University of Montreal Public Health Research Institute (IRSPUM), Montreal, Quebec, Canada.

Received: 15 December 2014 Accepted: 23 July 2015

Published online: 30 July 2015

\section{References}

1. WHO. Global strategy for dengue prevention and control 2012-2020. Geneva: WHO. World Health Organization; 2012.

2. Gubler DJ. Dengue/dengue haemorrhagic fever: history and current status. Novartis Found Symp. 2006;277:3-16. discussion 16-22, 71-13, 251-253.

3. Murray NEA, Quam MB, Wilder-Smith A. Epidemiology of dengue: past, present and future prospects. Clin Epidemiol. 2013:5:299.

4. Bhatt S, Gething PW, Brady OJ, Messina JP, Farlow AW, Moyes CL, et al. The global distribution and burden of dengue. Nature. 2013;496:504-7.

5. Messina JP, Brady OJ, Scott TW, Zou C, Pigott DM, Duda KA, et al. Global spread of dengue virus types: mapping the 70 year history. Trends Microbiol. 2014:22(3):138-46.

6. Guzman MG, Halstead SB, Artsob H, Buchy P, Farrar J, Gubler DJ, et al. Dengue: a continuing global threat. Nat Rev Microbiol. 2010;8:S7-16.

7. Gubler DJ. Epidemic dengue/dengue hemorrhagic fever as a public health, social and economic problem in the 21st century. Trends Microbiol. 2002;10(2):100-3.

8. Tuiskunen Bäck A, Lundkvist $\AA$. Dengue viruses - an overview. Infect Ecology Epidemiol. 2013;3(2013):18839.

9. Rodriguez-Roche R, Gould EA. Understanding the dengue viruses and progress towards their control. Bio Med Res Int. 2013;2013:20.
10. Huy NT, Van Giang T, Thuy DHD, Kikuchi M, Hien TT, Zamora J, et al. Factors associated with dengue shock syndrome: a systematic review and meta-analysis. PLoS Negl Trop Dis. 2013;7(9), e2412.

11. Cafferata ML, Bardach A, Rey-Ares L, Alcaraz A, Cormick G, Gibbons L, et al, Dengue epidemiology and burden of disease in Latin America and the Caribbean: a systematic review of the literature and meta-analysis. Value in Health Regional Issues. 2013;2(3):347-56.

12. Gibbons R, Vaughn D. Dengue: an escalating problem. BMJ. 2002;324(7353):1563.

13. WHO. Dengue and severe dengue/Global burden of dengue. Fact sheet N¹17. Geneva: World Health Organization; 2012.

14. Guzmán MG, Kouri G. Dengue: an update. Lancet Infect Dis. 2002;2(1):33-42.

15. San Martín JL, Brathwaite O, Zambrano B, Solórzano JO, Bouckenooghe A, Dayan $\mathrm{GH}$, et al. The epidemiology of dengue in the Americas over the last three decades: a worrisome reality. Am J Trop Med Hyg. 2010;82(1):128-35.

16. Solar O, Irwin A. A conceptual framework for action on the social determinants of health. In: Discussion Paper Series on Social Determinants of Health, No 2. Geneva: World Health Organization; 2010.

17. Marmot M, Wilkinson R. Social determinants of health: the solid facts. 2nd ed. Copenhagen: World Health Organization; 2003.

18. Commission on Social Determinants of Health-CSDH. Closing the gap in a generation: health equity through action on the social determinants of health. Final report of the Commission on Social Determinants of Health Geneva: World Health Organization; 2008. p. 256

19. Blas E, Kurup AS. Equity, social determinants and public health programmes. Geneva: World Health Organization; 2010.

20. Carabalí JM, Hendrickx D. Dengue and health care access: the role of social determinants of health in dengue surveillance in Colombia. Glob Health Promot. 2012:19(4):45-50.

21. Khun S, Manderson L. Poverty, user fees and ability to pay for health care for children with suspected dengue in rural Cambodia. Int J Equity in Health. 2008;7(1):10.

22. Arksey H, O'Malley L. Scoping studies: towards a methodological framework. Int J Social Res Methodol. 2005;8(1):19-32.

23. WHO. Dengue guidelines for diagnosis, treatment, prevention and control - New edition. Geneva: World Health Organization; 2009.

24. von Elm E, Altman DG, Egger M, Pocock SJ, Gøtzsche PC, Vandenbroucke JP. The Strengthening the Reporting of Observational Studies in Epidemiology (STROBE) Statement: Guidelines for reporting observational studies. Prev Med. 2007;45(4):247-51.

25. Hsieh H-F, Shannon SE. Three approaches to qualitative content analysis. Qual Health Res. 2005;15(9):1277-88.

26. World Health Organization. Dengue: guidelines for diagnosis, treatment, prevention and control. 2nd Edition, WHO Library Cataloguing-inPublication Data Geneva: World Health Organization; 1997.

27. Cardoso IM, Cabidelle ASA, Borges PCL, Lang CF, Calenti FG, Nogueira LO, et al. Dengue: clinical forms and risk groups in a high incidence city in the southeastern region of Brazil. Rev Soc Bras Med Trop. 2011;44(4):430-5.

28. Corwin AL, Larasati RP, Bangs MJ, Wuryadi S, Arjoso S, Sukri N, et al. Epidemic dengue transmission in southern Sumatra, Indonesia. Trans $\mathrm{R}$ Soc Trop Med Hyg. 2001;95(3):257-65.

29. Guzmán MG, Alvarez M, Rodriguez R, Rosario D, Vázquez $S$, Valdés $L$, et al. Fatal dengue hemorrhagic fever in Cuba, 1997. Int J Infect Dis. 1999;3(3):130-5.

30. Sam SS, Omar SF, Teoh BT, Abd-Jamil J, AbuBakar S. Review of Dengue hemorrhagic fever fatal cases seen among adults: a retrospective study. PLoS Negl Trop Dis. 2013;7(5), e2194.

31. Bunnag T, Kalayanarooj S. Dengue shock syndrome at the emergency room of Queen Sirikit National Institute of Child Health, Bangkok, Thailand. J Med Assoc Thai. 2011:94 Suppl 3:S57-63.

32. Fajardo-Dolci G, Meljem-Moctezuma J, Vicente-González E, Venegas-Páez FV, Villalba-Espinoza I, Pérez-Cardoso AL, et al. Defunciones por dengue en México Análisis del año 2009. Rev Med Inst Mex Seguro Soc. 2012;50(6):589-98

33. Sharp TM, Hunsperger E, Santiago GA, Muñoz-Jordan JL, Santiago LM, Rivera A, et al. Virus-specific differences in rates of disease during the 2010 dengue epidemic in Puerto Rico. PLoS Negl Trop Dis. 2013;7(4), e2159.

34. Wang C-C, Lee I-K, Su M-C, Lin H-I, Huang Y-C, Liu S-F, et al. Differences in clinical and laboratory characteristics and disease severity between children and adults with dengue virus infection in Taiwan, 2002. Trans R Soc Trop Med Hyg. 2009;103(9):871-7. 
35. Md P, Figueiredo M. Mortalidade por dengue no estado da Bahia. Revista Baiana de Saúde Pública. 2011;35(3):687-94.

36. Cordeiro MT, Schatzmayr HG, Nogueira RMR, Oliveira VF, Melo WT, Carvalho EF. Dengue and dengue hemorrhagic fever in the State of Pernambuco, 1995-2006. Rev Soc Bras Med Trop. 2007;40(6):605-11.

37. González D, Castro OE, Kourí G, Perez J, Martinez E, Vazquez S, et al. Classical dengue hemorrhagic fever resulting from two dengue infections spaced 20 years or more apart: Havana, Dengue 3 epidemic, 2001-2002. Int J Infect Dis. 2005;9(5):280-5.

38. Salgado DM, Panqueba CA, Vega MR, Garzón M, Castro D, Rodríguez JA Mortalidad por dengue hemorrágico en niños en Colombia: más allá del choque / Dengue hemorrhagic fever mortality in children: beyond shock. Infectio. 2008;12(1):21-7.

39. Contreras-Arita A, Villatoro-Godoy G. Perfil Clínico-epidemiológico del dengue hemorrágico en niños atendidos en el Hospital Materno Infantil. Rev Med Post Unah. 1999;4(2):122-8.

40. Tomashek KM, Gregory CJ, Rivera Sanchez A, Bartek MA, Garcia Rivera EJ,

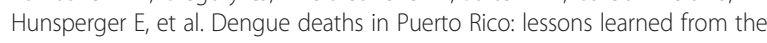
2007 epidemic. PLoS Negl Trop Dis. 2012;6(4), e1614.

41. Raghupathy R, Chaturvedi UC, Al-Sayer H, Elbishbishi EA, Agarwal R, Nagar $\mathrm{R}$, et al. Elevated levels of IL-8 in dengue hemorrhagic fever. J Med Virol. 1998;56(3):280-5.

42. Ahmed S, Mohammad WW, Hamid F, Akhter A, Afzal RK, Mahmood A. The 2011 dengue haemorrhagic fever outbreak in Lahore - an account of clinical parameters and pattern of haemorrhagic complications. J College Physicians and Surgeons-Pakistan: JCPSP. 2013;23(7):463-7.

43. Arismendi-Morillo G, Mauriello-Rivas C, Maldonado-Reverol M, FernándezAbreu M, Larreal M, Torres-Nava G, et al. Correlación clínico-patológica en casos fatales de dengue en Maracaibo. Venezuela Revista Cubana de Medicina Tropical. 2011;63(1):44-51.

44. Carod-Artal FJ, Wichmann O, Farrar J, Gascón J. Neurological complications of dengue virus infection. The Lancet Neurology. 2013;12(9):906-19.

45. Mohamed NA, El-Raoof EA, Ibraheem HA. Respiratory manifestations of dengue fever in Taiz-Yemen. Egyptian Journal of Chest Diseases and Tuberculosis. 2013;62(2):319-23.

46. Azevedo LS, Carvalho DB, Matuck T, Alvarenga MF, Morgado L, Magalhaes I, et al. Dengue in renal transplant patients: a retrospective analysis. Transplantation. 2007;84(6):792-4.

47. Karunakaran A, llyas WM, Sheen SF, Jose NK, Nujum ZT. Risk factors of mortality among dengue patients admitted to a tertiary care setting in Kerala, India. J Infect Public Health. 2013;7(2):114-20.

48. Chesneau P, Mehdaoui H, Drault JN, de Heaulmes O, Flament F, Elisabeth $L$. Dengue hémorragique chez un patient traité au long cours par un antiagrégant plaquettaire : à propos d'un cas mortel en Martinique. Réanimation Urgences. 1998;7(6, Part 1):665-7.

49. Adam I, Jumaa AM, Elbashir HM, Karsany MS. Maternal and perinatal outcomes of dengue in PortSudan, Eastern Sudan. Virol J. 2010;7:153.

50. Pouliot SH, Xiong X, Harville E, Paz-Soldan V, Tomashek KM, Breart G, et al. Maternal dengue and pregnancy outcomes: a systematic review. Obstet Gynecol Surv. 2010;65(2):107-18.

51. Mota AKM, Miranda Filho AL, Saraceni V, Koifman S. Mortalidade materna e incidência de dengue na Região Sudeste do Brasil: estudo ecológico no período 2001-2005. Cad Saude Publica. 2012;28(6):1057-66.

52. Jackson ST, Mullings A, Bennett F, Khan C, Gordon-Strachan G, Rhoden T. Dengue infection in patients presenting with neurological manifestations in a dengue endemic population. West Indian Med J. 2008;57(4):373-6.

53. Verma $R$, Varatharaj A. Epilepsia partialis continua as a manifestation of dengue encephalitis. Epilepsy Behav. 2011;20(2):395-7.

54. Tsai J-J, Hsieh M-H, Liu L-T, Hsiao H-M, Perng GC. Mortality from septic shock in a dengue infected patient: a case report. Southeast Asian J Trop Med Public Health. 2013;44(4):623-9.

55. Lee IK, Liu JW, Yang KD. Fatal dengue hemorrhagic fever in adults: emphasizing the evolutionary pre-fatal clinical and laboratory manifestations. PLoS Negl Trop Dis. 2012;6(2), e1532.

56. Arboleda M, Campuzano M, Restrepo BN, Cartagena G. Caracterización clínica de los casos de dengue hospitalizados en la E.S.E. Hospital "Antonio Roldán Betancur", Apartadó, Antioquia, Colombia, 2000. Biomedica. 2006:26(2):286-94

57. Vita WP, Nicolai CCA, Azevedo MB, Souza MF, Baran M. Dengue: alertas clínicos e laboratoriais da evolução grave da doença. Rev Soc Bras Med Trop. 2009;7(1):11-4
58. Ron-Guerrero CS, Ron-Magaña AL. Dengue fatal: reporte de cuatro casos en Nayarit, México. Medicina Interna de México. 2011;27(4):386.

59. Casali CG, Pereira MRR, Santos LMJG, Passos MNP, Fortes BDPMD, Ortiz Valencia LI, et al. A epidemia de dengue/dengue hemorrágico no município do Rio de Janeiro, 2001/2002. Rev Soc Bras Med Trop. 2004;37(4):296-9.

60. Alejandria MM: Dengue haemorrhagic fever or dengue shock syndrome in children. Clinical Evidence 2009; published online 12 January 2009.

61. Wichmann O, Hongsiriwon S, Bowonwatanuwong C, Chotivanich K, Sukthana Y, Pukrittayakamee S. Risk factors and clinical features associated with severe dengue infection in adults and children during the 2001 epidemic in Chonburi, Thailand. Trop Med Int Health. 2004;9(9):1022-9.

62. Ocazionez RE, Cortes FM, Villar LA, Gomez SY. Temporal distribution of dengue virus serotypes in Colombian endemic area and dengue incidence. Re-introduction of dengue-3 associated to mild febrile illness and primary infection. Mem Inst Oswaldo Cruz. 2006;101(7):725-31.

63. Méndez Á, González G. Manifestaciones clínicas inusuales del dengue hemorrágico en niños. Biomedica. 2006;26(1):61-70.

64. Misra UK, Kalita J, Syam UK, Dhole TN. Neurological manifestations of dengue virus infection. J Neurol Sci. 2006;244(1-2):117-22.

65. Chaudhuri $M$, Pahari A. Dengue: clinical issues in management. Apollo Medicine. 2005;2(4):364-73

66. Ho T-S, Wang S-M, Lin Y-S, Liu C-C. Clinical and laboratory predictive markers for acute dengue infection. J Biomed Sci. 2013;20(1):75.

67. Kamath SR, Ranjit S. Clinical features, complications and atypical manifestations of children with severe forms of dengue hemorrhagic fever in South India. Indian J Pediatr. 2006;73(10):889-95.

68. Lee VJ, Lye DCB, Sun Y, Fernandez G, Ong A, Leo YS. Predictive value of simple clinical and laboratory variables for dengue hemorrhagic fever in adults. J Clin Virol. 2008;42(1):34-9.

69. Rigau-Pérez JG. Clinical manifestations of dengue hemorrhagic fever in Puerto Rico, 1990-1991. Rev Panam Salud Publica. 1997;1 (6):435-43.

70. Rocha LA, Tauil PL. Dengue em criança: aspectos clínicos e epidemiológicos, Manaus, Estado do Amazonas, no período de 2006 e 2007. Rev Soc Bras Med Trop. 2009;42(1):18-22.

71. Shamim M. Frequency, pattern and management of acute abdomen in dengue fever in Karachi, Pakistan. Asian J Surg. 2010;33(3):107-13.

72. Sukri NC, Laras K, Wandra T, Didi S, Larasati RP, Rachdyatmaka JR, et al. Transmission of epidemic dengue hemorrhagic fever in easternmost Indonesia. Am J Trop Med Hyg. 2003;68(5):529-35.

73. Almas A, Parkash O, Akhter J. Clinical factors associated with mortality in dengue infection at a tertiary care center. Southeast Asian J Trop Med Public Health. 2010;41(2):333-40.

74. Araújo FMC, Araújo MS, Nogueira RMR, Brilhante RSN, Oliveira DN, Rocha MFG, et al. Central nervous system involvement in dengue: A study in fata cases from a dengue endemic area. Neurology. 2012;78(10):736-42.

75. Juneja D, Nasa P, Singh O, Javeri Y, Uniyal B, Dang R. Clinical profile, intensive care unit course, and outcome of patients admitted in intensive care unit with dengue. J Crit Care. 2011;26(5):449-52.

76. Malavige GN, Velathanthiri VGNS, Wijewickrama ES, Fernando S, Jayaratne SD, Aaskov J, et al. Patterns of disease among adults hospitalized with dengue infections. QJM. 2006;99(5):299-305.

77. Montenegro D, Lacerda HR, Lira TM, Oliveira DSC, Lima AAF, Guimarães $M J B$, et al. Aspectos clínicos e epidemiológicos da epidemia de denque no Recife, PE, em 2002. Revista da Sociedade Brasileira de Medicini Tropical. 2006;39(1):9-13

78. Navarrete-Espinosa J, Gómez-Dantés H, Germán Celis-Quintal J, Vázquez-Martínez $J$ L. Clinical profile of dengue hemorrhagic fever cases in Mexico. Salud Publica Mex. 2005:47(3):193-200.

79. Nisalak A, Endy TP, Nimmannitya S, Kalayanarooj S, Thisayakorn U, Scott RM, et al. Serotype-splecific dengue virus circulation and dengue disease in Bangkok, Thailand from 1973 to 1999. Am J Trop Med Hyg. 2003;68(2):191-202

80. Ong A, Sandar M, Chen MI, Sin LY. Fatal dengue hemorrhagic fever in adults during a dengue epidemic in Singapore. Int J Infect Dis. 2007;11(3):263-7.

81. Schmitz L, Prayag S, Varghese S, Jog S, Bhargav-Patil P, Yadav A, et al. Nonhematological organ dysfunction and positive fluid balance are important determinants of outcome in adults with severe dengue infection: a multicenter study from India. J Crit Care. 2011;26(5):441-8.

82. Janssen HLA, Bienfait HP, Jansen CL, van Duinen SG, Vriesendorp R, Schimsheimer RJ, et al. Fatal cerebral oedema associated with primary dengue infection. J Infect. 1998;36(3):344-6. 
83. Pontes RJS, Ruffino-Netto A. Vigilância e busca ativa de casos suspeitos de dengue hemorrágico em Ribeirão Preto, São Paulo / Surveillance and active search system for suspect cases of hemorrhagic dengue in Ribeirão Preto, São Paulo. Rev Panam Salud Publica. 1997;11(3):186-92.

84. Lee $\mathrm{C}-\mathrm{H}$, Teo C, Low AF. Fulminant dengue myocarditis masquerading as acute myocardial infarction. Int J Cardiol. 2009;136(3):e69-71.

85. Marques N, Gan V, Leo Y-S. Dengue myocarditis in Singapore: two case reports. Infection. 2013;41(3):709-14.

86. Mok Y, Quah J, Siau C. A rare but potentially lethal complication of dengue. Asian Pacific J Tropical Med. 2013;6(6):500-1.

87. Teixeira MG, Costa MCN, Barreto F, Barreto ML. Dengue: twenty-five years since reemergence in Brazil: [review] / Dengue: vinte e cinco anos da reemergência no Brasil: [revisão]. Cad Saude Publica. 2009;25(supl.1):S7-18.

88. Moraes $\mathrm{GH}$, de Fatima DE, Duarte EC. Determinants of mortality from severe dengue in Brazil: a population-based case-control study. Am J Trop Med Hyg. 2013;88(4):670-6.

89. Jensenius M, Berild D, Ormaasen V, Mæhlen J, Lindegren G, Falk Kl. Fatal subarachnoidal haemorrhage in a Norwegian traveller with dengue virus infection. Scand J Infect Dis. 2007;39(3):272-4.

90. Huhtamo E, Vuorinen S, Uzcátegui NY, Vapalahti O, Haapasalo H, Lumio J. Fatal dengue virus infection in a Finnish traveler. J Clin Virol. 2006;37(4):323-6

91. Mia MS, Begum RA, Er AC, Abidin RDZRZ, Pereira JJ. Trends of dengue infections in Malaysia, 2000-2010. Asian Pacific J Tropical Med. 2013;6(6):462-6.

92. Díaz-Quijano FA, Waldman EA. Factors associated with dengue mortality in Latin America and the Caribbean, 1995-2009: an ecological study. Am J Trop Med Hyg. 2012;86(2):328-34

93. Figueiró AC, Hartz ZMA, Brito CAA, Samico I, Siqueira Filha NT, Cazarin G, et al. Óbito por dengue como evento sentinela para avaliação da qualidade da assistência: estudo de caso em dois municípios da Região Nordeste, Brasil, 2008. Cad Saude Publica. 2011;27(12):2373-85.

94. Chakravarti A, Arora R, Luxemburger C. Fifty years of dengue in India. Trans R Soc Trop Med Hyg. 2012;106(5):273-82.

95. Larrieu S, Cassadou S, Rosine J, Chappert JL, Blateau A, Ledrans M, et al. Lessons raised by the major 2010 dengue epidemics in the French West Indies. Acta Trop. 2014;131:37-40.

96. Nogueira RMR, Araújo JMG, Schatzmayr HG. Dengue viruses in Brazil, 1986-2006. Rev Panam Salud Publica. 2007;22(5):358-63.

97. Souza TBB, Dias JP. Perfil epidemiológico da dengue no Município de Itabuna (BA), 2000 jun. 2009. Revista Baiana de Saúde Pública. 2010:34:3.

98. Guzmán MG, Kourí G, Valdés L, Bravo J, Vázquez S, Halstead S. Aumento de la gravedad de las infecciones secundarias por dengue-2: tasa de mortalidad en los brotes cubanos de 1981 y 1997. Revista Panamerica de Salud Pública. 2002;11(4):223-7.

99. Nogueira R, Filippis A, Coelho J, Sequeira P, Schatzmayr H, Paiva F, et al. Dengue virus infection of the central nervous system (CNS): a case report from Brazil. Southeast Asian J Trop Med Public Health. 2002;33(1):68-71.

100. Nogueira R, Schatzmayr H, de Filippis A, dos Santos F, da Cunha R, Coelho J, et al. Dengue virus type 3, Brazil, 2002. Emerg Infect Dis. 2005;11(9):6.

101. Ramos C, Sánchez G, Pando RH, Baquera J, Hernández D, Mota J, et al. Dengue virus in the brain of a fatal case of hemorrhagic dengue fever. J Neurovirol. 1998;4(4):465-8.

102. Chheng K, Carter MJ, Emary K, Chanpheaktra N, Moore CE, Stoesser N, et al. A prospective study of the causes of febrile illness requiring hospitalization in children in Cambodia. PLoS One. 2013;8(4), e60634.

103. Fiestas Solórzano V, Sihuincha Maldonado M, Donaires Toscano F. Características clínicas de pacientes internados en el Hospital de Apoyo de lquitos" César Garayar García" durante la epidemia de dengue, enero-febrero de 2011. Rev Peru Med Exp Salud Publica. 2011;28(1):78-82.

104. Phelan JC, Link BG, Tehranifar P. Social conditions as fundamental causes of health inequalities: theory, evidence, and policy implications. J Health Soc Behav. 2010;51(1 suppl):S28-40.

105. Pudrovska T. Early-life socioeconomic status and mortality at three life course stages: an increasing within-cohort inequality. J Health Soc Behav. 2014;55(2):181-95

106. Azoh Barry J. Social sciences research on infectious diseases of poverty: too little and too late? PLoS Negl Trop Dis. 2014;8(6), e2803.

107. Halstead SB. Dengue in the Americas and Southeast Asia: do they differ? Rev Panam Salud Publica. 2006;20(6):407-15.
108. Amarasinghe A, Kuritsky J, Letson G, Margolis $\mathrm{H}$. Dengue virus infection in Africa. Emerg Infect Dis. 2011;17(8):1349-54.

109. Blanton RE, Silva LK, Morato VG, Parrado AR, Dias JP, Melo PRS, et al. Genetic ancestry and income are associated with denque hemorrhagic fever in a highly admixed population. Eur J Hum Genet. 2008;16(6):762-5.

110. Guzman $M G$, Kouri $G$. Dengue and dengue hemorrhagic fever in the Americas: lessons and challenges. J Clin Virol. 2003;27(1):1-13.

111. Restrepo BN, Arboleda M, Ramírez R, Alvarez G. Actividad sérica de la acetilhidrolasa del factor activador de plaquetas en pacientes afrodescendientes y mestizos con dengue, Colombia. Biomedica. 2011;31:4.

112. Sierra BC, Kourí G, Guzmán MG. Race: a risk factor for dengue hemorrhagic fever. Arch Virol. 2007;152(3):533-42.

113. Halstead S. Pathogenesis of dengue: challenges to molecular biology. Science. 1988;239(4839):476-81.

114. Arauz MJ, Ridde V, Hernández LM, Charris Y, Carabali M, Villar LÁ. Developing a social autopsy tool for dengue mortality: a pilot study. PLoS One. 2015;10(2), e0117455.

\section{Submit your next manuscript to BioMed Central and take full advantage of:}

- Convenient online submission

- Thorough peer review

- No space constraints or color figure charges

- Immediate publication on acceptance

- Inclusion in PubMed, CAS, Scopus and Google Scholar

- Research which is freely available for redistribution 